\title{
Importância atribuída pelos Gestores às funções de Controladoria nas Prefeituras Municipais da Associação dos Municípios da Zona de Produção do Rio Grande do Sul
}

\author{
Natália da Silva Schio \\ Mestrado em andamento em Ciências Contábeis e Administração pela Universidade \\ Comunitária da Região de Chapecó - UNOCHAPECÓ \\ Servidão Anjo da Guarda, 295-D. Efapi. Chapecó/SC. CEP: 89.809-900 \\ E-mail:n.schio@unochapeco.edu.br
}

Rodney Wernke Doutorado em Engenharia de Produção pela Universidade Federal de Santa Catarina UFSC Professor da Universidade do Sul de Santa Catarina - UNISUL Avenida José A. Moreira, 787. Dehon. Tubarão/SC. CEP 88.704-900

E-mail: rodneywernke1@hotmail.com

Antônio Zanin Doutorado em Engenharia de Produção pela Universidade Federal do Rio Grande do Sul - UFRGS Professor da Universidade Comunitária da Região de Chapecó - UNOCHAPECÓ Servidão Anjo da Guarda, 295-D. Efapi. Chapecó/SC. CEP: 89.809-900 E-mail:zanin@unochapeco.edu.br

\section{RESUMO}

O artigo objetivou identificar os níveis da importância atribuída às funções de controladoria pelos gestores das prefeituras pertencentes à Associação dos Municípios da Zona de Produção do Rio Grande do Sul (AMZOP). A revisão da literatura abordou aspectos da controladoria no setor público, as funções de controladoria e estudos assemelhados. Foi empregada metodologia classificável como quantitativa e descritiva, com levantamento de dados por meio de questionário. Quanto aos resultados, foi apurado que as funções de controladoria mais valorizadas são Controle Interno, Contábil e Tributário. Além disso, na maioria das funções (e respectivas atividades que as integram) não há uma distinção estatisticamente relevante acerca da importância atribuída às funções da controladoria pelos gestores municipais. Somente em dois casos: quanto ao número de habitantes do município (Proteção e Controle de Ativos e Contratação e Controle de Seguros) e um caso nas perspectivas quanto ao cargo ocupado (Fiscalização e Cumprimento de Obrigações Legais/Fiscais) e ao tipo de graduação do gestor municipal (Acompanhamento e Realização de Auditoria) existem indicativos de divergência nos níveis médios da importância atribuída. A contribuição do estudo consiste em priorizar a identificação da importância que as funções da controladoria têm para os gestores que usam as informações provenientes do trabalho 
Importância atribuída pelos Gestores às funções de Controladoria nas Prefeituras Municipais da Associação dos Municípios da Zona de Produção do Rio Grande do Sul Natália da Silva Schio, Rodney Wernke, Antônio Zanin

executado pelos controllers nos municípios abrangidos, distinguindo-se de estudos que focaram na opinião dos controllers a respeito do próprio trabalho.

Palavras-chave: Controladoria Pública. Funções de Controladoria. Prefeituras Municipais.

Importance attributed by the Managers to the functions of Controller in the Municipal Preectures of the Association of Municipalities of the Rio Grande do Sul Production Zone

\section{ABSTRACT}

The objective of this paper was to identify the levels of importance attributed to controller functions by managers of municipalities belonging to the Association of Municipalities of the Rio Grande do Sul Production Zone (AMZOP). The literature review addressed aspects of public sector controllership, control functions, and similar studies. Methodology was classified as quantitative and descriptive, with data collection by means of a survey. Regarding the results, it was found that the most valued control functions are Internal, Accounting and Tax Control. Moreover, in most of the functions (and their activities that integrate them) there is no statistically relevant distinction about the importance attributed to the functions of the controller by the municipal managers. Only in two cases regarding the number of inhabitants of the municipality (Protection and Control of Assets and Insurance Contracts and Control) and one case in the outlook regarding the position occupied (Inspection and Compliance of Legal / Fiscal Obligations) and the type of graduation of the manager (Monitoring and Auditing) there are indications of divergence in the average levels of importance attributed. The contribution of the study consists in prioritizing the identification of the importance that the functions of the controller have for the managers who use the information coming from the work performed by the controllers in the municipalities covered, being distinguished from studies that focused on the opinion of the controllers regarding the work itself.

Keywords: Public Controller. Controlling Functions. City Halls.

\section{INTRODUÇÃO}

A controladoria tem exercido um papel de destaque na gestão estratégica das organizações, sejam públicas ou privadas. Fernandes e Galvão (2016) relatam que, nas 
Importância atribuída pelos Gestores às funções de Controladoria nas Prefeituras Municipais da Associação dos Municípios da Zona de Produção do Rio Grande do Sul Natália da Silva Schio, Rodney Wernke, Antônio Zanin

instituições privadas, as funções de controladoria são bem aceitas em médias e grandes empresas, visto que se adaptam à estrutura organizacional e de custos dessas entidades. Nessa direção, pelo uso de conceitos e instrumentos desta área, a controladoria tende a contribuir para melhorar o controle das atividades e melhorar a competitividade da empresa.

No caso da administração pública, a controladoria coopera para o alcance de programas e metas do governo mediante ações eficientes e legais, construindo serviços e condições para o bem-estar da população (Silva, Carneiro, \& Ramos, 2015). Nesse rumo, para Catelli (2012), a missão da Controladoria é coordenar a gestão econômica da organização pública, sendo responsável pela elaboração dos planos estratégicos e operacionais, além da execução e do controle respectivos.

Assim, na busca por uma administração pública mais transparente e resolutiva, criou-se o setor de controle interno, o qual está inserido também no âmbito das prefeituras municipais. Na visão de Barnier (2015), o conceito de controle interno não é intuitivo e sua compreensão está relacionada à sua eficácia, isto é, para que a organização consiga conduzir suas ações de controle e gerenciá-lo de maneira concreta e adequada, uma das principais dificuldades é estabelecer uma linguagem comum sobre controles a partir de seu conceito.

Nesse sentido, no contexto da administração pública, os órgãos de controle têm papel importante, já que são responsáveis por prover diretrizes às instituições públicas. À vista disso, é relevante conhecer o desempenho dessas organizações, bem como as potencialidades da aplicabilidade dos conceitos teóricos de controladoria nessas entidades (Durigon \& Diehl, 2016).

No caso das instituições públicas brasileiras, o setor de controle interno passou a ser obrigatório no artigo 70 da Constituição Federal (1988), que determina que a fiscalização contábil, financeira, orçamentária, operacional e patrimonial da União e das entidades da administração direta e indireta, quanto à legalidade, legitimidade, economicidade, aplicação das subvenções e renúncia de receitas, será exercida pelo 
Importância atribuída pelos Gestores às funções de Controladoria nas Prefeituras Municipais da Associação dos Municípios da Zona de Produção do Rio Grande do Sul Natália da Silva Schio, Rodney Wernke, Antônio Zanin

Congresso Nacional, mediante controle externo, e pelo sistema de controle interno de cada Poder.

Porém, tanto em entidades públicas quanto em empresas privadas, a concreta definição das funções da controladoria é uma tarefa complexa, considerando as várias atividades possíveis a serem desempenhadas por essa unidade organizacional. Diante disso, Slomski (2009) aduz que, de forma abrangente, a controladoria reflete a busca pelo atingimento do nível gerencial ótimo, em que o objetivo é obter os melhores resultados por meio dos recursos disponíveis.

Nessa direção, as novas funções do sistema de controle interno propostas para as instituições públicas (Conselho Federal de Contabilidade [CFC], 2008; Organização para a Cooperação e Desenvolvimento Econômico [OCDE], 2011) envolvem auditoria, controle contábil, fiscalização de obras, acompanhamento de políticas públicas, exames de licitações e contratos, promoção da transparência municipal, capacitação dos servidores e estímulo ao controle social. Ainda sobre as funções públicas, Silva (2013) destaca como funções estratégicas da Controladoria a promoção do controle social, o suporte e a orientação aos gestores de recursos públicos, o fornecimento de informações estratégicas e o acompanhamento à racionalização dos gastos.

Apesar das divergências sobre as funções da controladoria na administração pública, estas podem ser executadas, com maior ou menor intensidade, nas prefeituras municipais brasileiras, o que pode estar vinculado à importância que os gestores dão a esse aspecto gerencial. Nesse sentido, este estudo pretende obter resposta para a seguinte pergunta de pesquisa: quais os níveis da importância atribuída às funções de controladoria pelos gestores das prefeituras municipais pertencentes à Associação dos Municípios da Zona de Produção do Rio Grande do Sul (AMZOP)? Para tal finalidade, foi estabelecido o objetivo de identificar os níveis da importância atribuída às funções de controladoria pelos gestores das prefeituras pertencentes à AMZOP.

Uma pesquisa com este foco se justifica por, pelo menos, dois aspectos. O primeiro está relacionado à importância da área de controladoria no âmbito das 
Importância atribuída pelos Gestores às funções de Controladoria nas Prefeituras Municipais da Associação dos Municípios da Zona de Produção do Rio Grande do Sul Natália da Silva Schio, Rodney Wernke, Antônio Zanin

entidades públicas, tanto para atendimento da legislação a respeito, quanto para a melhoria da transparência e da qualidade dos serviços de informação acerca dos gastos públicos (Macedo \& Lavarda, 2013; Souza Júnior \& Silva, 2016).

O segundo fator relevante está baseado na possibilidade de conhecer quais são as funções executadas pela controladoria das prefeituras abrangidas que os gestores públicos municipais mais valorizam. Com isso, poderá ser evidenciado se há necessidade de aprimoramento de determinadas funções e respectivas atividades, bem como auxiliar na gestão dos municípios pelo fortalecimento daqueles pontos que podem prejudicar o atendimento de demandas externas ou internas relevantes (Henrique, Chagas, Guimarães, \& Leal Junior, 2016, Bonetti, Wernke, \& Zanin, 2017).

\section{REVISÃO DA LITERATURA}

A área da Controladoria surgiu na década de 1960 com o advento da industrialização, principalmente das grandes corporações americanas, de modo a impulsionar a constituição deste ramo do conhecimento contábil (Voght, Degenhart, \& Lavarda, 2017). Porém a controladoria pública no Brasil surgiu em virtude das exigências legais impostas aos gestores públicos, o que decorreu da crescente demanda da sociedade pela oferta de serviços de qualidade, além da cobrança por transparência e ética nas ações do governo (Macedo \& Lavarda, 2013).

Nesse contexto, em ambientes de órgãos públicos há uma preocupação em bem administrar, visto que os governantes prestam serviços (de natureza política, econômica, de saúde, educação e de infraestrutura, entre outros) aos cidadãos diretamente, o que implica buscar qualidade dos serviços de forma constante e transparente. Essa preocupação pode estar relacionada com a necessidade de acompanhar a execução de programas, identificando possíveis falhas e desvios com o fito de aprimorar a administração pública por meio da adoção de controles internos adequados (Souza Júnior \& Silva, 2016). 
Importância atribuída pelos Gestores às funções de Controladoria nas Prefeituras Municipais da Associação dos Municípios da Zona de Produção do Rio Grande do Sul Natália da Silva Schio, Rodney Wernke, Antônio Zanin

\subsection{Legislação sobre órgãos públicos de controle interno}

No caso das instituições públicas brasileiras, o embasamento legal da obrigatoriedade de implantação dos órgãos de controle interno ocorreu em virtude do artigo 31 da Constituição Federal de 1988, o qual afirma que a fiscalização dos municípios será exercida pelo respectivo Poder Legislativo Municipal, mediante controle externo executado com apoio do Tribunal de Contas do Estado e pelo sistema de controle interno do próprio município.

Além disso, de acordo com Beuren e Zonatto (2014), com a reforma do Estado e a publicação da Lei de Responsabilidade Fiscal (LRF), conceitos relacionados com a economicidade, eficiência, eficácia e qualidade passaram a ser mais explorados, visando ao desenvolvimento de uma cultura gerencial também no setor público.

A partir dessa realidade, é possível considerar que a controladoria também é relevante para os entes públicos porque tende a alinhar o fluxo de informações com o intuito de alcançar os objetivos traçados pelo administrador público. Acerca disso, a Federação Internacional de Contadores (IFAC) argumenta que as organizações públicas devem exercer controle de acordo com os princípios da boa governança, que incluem atividades de avaliação de sistemas gerenciais, monitoramento de aspectos financeiros, orçamentários e operacionais, realização da gestão de riscos, acompanhamento de auditorias internas e externas, instituição de controles internos e zelo pela utilização de normas contábeis apropriadas (Cavalcante, De Luca, Ponte, \& Gallon, 2012).

Nesse sentido, Macedo e Lavarda (2013) comentam que, no âmbito da administração pública, a controladoria deve acompanhar a execução orçamentária, medir os resultados atingidos no exercício, dar suporte aos gestores na tomada de decisão e produzir relatórios a respeito do fluxo das transações para, se necessário, redirecionar ou ajustar o foco dos gestores. 
Importância atribuída pelos Gestores às funções de Controladoria nas Prefeituras Municipais da Associação dos Municípios da Zona de Produção do Rio Grande do Sul Natália da Silva Schio, Rodney Wernke, Antônio Zanin

\subsection{Funções da Controladoria}

A conceituação das funções da controladoria não é uma tarefa simples devido à diversidade de conceitos expostos na literatura (Suzart, Marcelino, \& Rocha, 2011), bem como pela inexistência de consenso a respeito (Assis, Silva, \& Catapan, 2016).

Além das indefinições existentes, Suzart et al. (2011) afirmam que a funções de controladoria também são influenciadas pela estrutura e pelo modelo de gestão das entidades. Relatam, porém, que existe um grupo de funções comuns que podem ser consideradas como funções típicas da controladoria, as quais são definidas por Willson, Roehl-Anderson e Bragg (1995) como: função de planejamento, função de controle, função informativa, função contábil e função complementar.

Sobre o tema, Borinelli (2006) propôs uma Estrutura Conceitual Básica (ECB) para a Controladoria, que foi utilizada como base para o questionário desta pesquisa:

a) Função Contábil: compreende as atividades relativas ao desenvolvimento da contabilidade societária (ou financeira) como gerenciar as atividades de contabilidade, implementar e manter todos os registros contábeis (processamento contábil), elaborar as demonstrações contábeis, atender aos agentes de mercado (stakeholders) em suas demandas informacionais, proceder à análise interpretativa das demonstrações contábeis e desenvolver políticas e procedimentos contábeis e de controle.

b) Função Gerencial-Estratégica: abrange as atividades relativas a prover informações de natureza contábil, patrimonial, econômica, financeira e não financeira ao processo de gestão como um todo, para que os gestores possam estar devidamente subsidiados em suas tomadas de decisões gerenciais e estratégicas. Além disso, está no escopo dessa função a atividade de coordenar os esforços dos gestores para que se obtenha sinergia no processo de alcance dos objetivos empresariais.

c) Função de Custos: envolve as atividades de registrar, mensurar, controlar, analisar e avaliar os custos da organização, incluindo análises gerenciais e 
Importância atribuída pelos Gestores às funções de Controladoria nas Prefeituras Municipais da Associação dos Municípios da Zona de Produção do Rio Grande do Sul Natália da Silva Schio, Rodney Wernke, Antônio Zanin

estratégicas referentes à viabilidade de lançamentos de produtos e serviços, resultados de produtos e serviços, de linhas de negócios e de clientes.

d) Função Tributária: refere-se às atividades relativas à contabilidade tributária (ou fiscal), ou seja, atender às obrigações legais, fiscais e acessórias previstas em leis e normas tributárias, o que significa registrar, apurar e controlar impostos, tributos e contribuições, bem como elaborar o planejamento tributário da organização.

e) Função de Proteção e Controle dos Ativos: compreende as atividades referentes a prover proteção aos ativos, como selecionar, analisar e contratar opções de seguros, além de controlá-los. Envolve ainda as atividades de registrar e controlar todos os bens da organização.

f) Função de Controle Interno: abrange as atividades referentes ao estabelecimento e monitoramento do sistema de controles internos, destinado a proteger o patrimônio organizacional e salvaguardar os interesses da entidade.

g) Função de Controle de Riscos: envolve as atividades de identificar, mensurar, analisar, avaliar, divulgar e controlar os diversos riscos envolvidos no negócio, bem como seus possíveis efeitos.

h) Função de Gestão de Informação: refere-se às atividades relativas a conceber modelos de informações e a gerenciar as informações contábeis, patrimoniais, de custos, gerenciais e estratégicas.

Por sua vez, Catelli (2012) assevera que as funções da Controladoria são executadas com o propósito de atingir os objetivos da organização. Destarte, pode-se definir que essas funções correspondem a subsidiar o processo de gestão, apoiar a avaliação de desempenho e de resultados, apoiar a avaliação de resultado econômico e de desempenho dos serviços.

Nesse rumo, o gestor dessas informações passa a ser o controller da organização, responsável por fornecer feedback a respeito para as diversas áreas da 
Importância atribuída pelos Gestores às funções de Controladoria nas Prefeituras Municipais da Associação dos Municípios da Zona de Produção do Rio Grande do Sul Natália da Silva Schio, Rodney Wernke, Antônio Zanin

entidade, mapear sistemas, examinar questões operacionais, implantar processos de melhoria, monitorar desempenhos e gerar relatórios de forma que os objetivos organizacionais sejam alcançados (Callado \& Amorim, 2017).

De forma assemelhada, a primeira definição dada à função do controller já considerava que esta vai além do registro de informações contábeis, uma vez que deve ser dotada de habilidades interpretativas e analíticas, informações estatísticas e contábeis feitas sob medida para suprir as precisões gerenciais. Com isso, subsidia os gestores com os dados necessários sobre a entidade e seu desempenho, possibilitando a análise das forças e fraquezas e auxiliando na formulação das estratégias de desenvolvimento (Silva et al., 2015).

\subsection{Estudos assemelhados}

Com o intuito de averiguar quais as funções de Controladoria que são mais evidenciadas na literatura, foram realizadas pesquisas no Portal de Periódicos Capes e Spell. Para tanto, foram utilizadas as expressões "Funções de Controladoria", "Controladoria Pública" e "Controladoria Privada" nos campos de busca "título", "palavra-chave" e "resumo". Além disso, foi utilizado, nessas buscas, o símbolo "*" (asterisco) junto às expressões citadas com o fito de expandir a pesquisa para termos assemelhados. A partir disso, obteve-se a lista de artigos resumidos na Figura 1 a seguir: 
Importância atribuída pelos Gestores às funções de Controladoria nas Prefeituras Municipais da Associação dos Municípios da Zona de Produção do Rio Grande do Sul

Natália da Silva Schio, Rodney Wernke, Antônio Zanin

\begin{tabular}{|c|c|c|}
\hline Autoria/Ano & Título & Objetivo \\
\hline $\begin{array}{l}\text { Oliveira Jr., } \\
\text { Junior e Lima } \\
\text { (2009) }\end{array}$ & $\begin{array}{c}\text { A controladoria nas } \\
\text { organizações públicas } \\
\text { municipais: um estudo de caso }\end{array}$ & $\begin{array}{c}\text { Avaliar se as práticas exercidas pela controladoria } \\
\text { geral do município pesquisado se assemelham às } \\
\text { funções de controladoria usualmente encontradas } \\
\text { na literatura, bem como avaliar o grau de } \\
\text { implementação das funções de controladoria. }\end{array}$ \\
\hline $\begin{array}{c}\text { Lunkes, } \\
\text { Schnorrenberger, } \\
\text { Gasparetto e } \\
\text { Vicente (2009) }\end{array}$ & $\begin{array}{c}\text { Considerações sobre as } \\
\text { funções da controladoria nos } \\
\text { Estados Unidos, Alemanha e } \\
\text { Brasil }\end{array}$ & $\begin{array}{l}\text { Identificar as funções da controladoria em manuais e } \\
\text { obras de referências dos Estados Unidos, Alemanha } \\
\text { e Brasil. }\end{array}$ \\
\hline $\begin{array}{l}\text { Fachini, Beuren e } \\
\text { Nascimento } \\
(2010)\end{array}$ & $\begin{array}{l}\text { Evidências de isomorfismo nas } \\
\text { funções da controladoria das } \\
\text { empresas familiares têxteis de } \\
\text { Santa Catarina } \\
\end{array}$ & $\begin{array}{l}\text { Verificar as evidências de isomorfismo nas funções } \\
\text { da controladoria das empresas familiares têxteis de } \\
\text { Santa Catarina. }\end{array}$ \\
\hline $\begin{array}{l}\text { Suzart, Marcelino } \\
\text { e Rocha (2011) }\end{array}$ & $\begin{array}{l}\text { As instituições brasileiras de } \\
\text { controladoria pública: teoria } \\
\text { versus prática }\end{array}$ & $\begin{array}{l}\text { Descrever sobre as competências, a } \\
\text { vinculação/subordinação e o modo de organização } \\
\text { das instituições brasileiras de controladoria pública. }\end{array}$ \\
\hline $\begin{array}{l}\text { Lunkes, } \\
\text { Schnorrenberger } \\
\text { e Rosa (2013) }\end{array}$ & $\begin{array}{l}\text { Funções da controladoria: uma } \\
\text { análise no cenário brasileiro }\end{array}$ & $\begin{array}{l}\text { Identificar e analisar as funções da controladoria } \\
\text { descritas em órgãos de representação, estudos } \\
\text { empíricos e apontados em obras e manuais de } \\
\text { referência, além de uma tentativa de consolidá-las. }\end{array}$ \\
\hline $\begin{array}{l}\text { Pinheiro, Lopes, } \\
\text { Rocha e Dias } \\
\text { Filho (2013) }\end{array}$ & $\begin{array}{c}\text { Desafios da controladoria } \\
\text { pública no contexto da Copa do } \\
\text { Mundo de } 2014\end{array}$ & $\begin{array}{l}\text { Identificar desafios enfrentados pela controladoria } \\
\text { pública no contexto da Copa do Mundo de } 2014 \text {. }\end{array}$ \\
\hline $\begin{array}{l}\text { Souza, Barros, } \\
\text { Araújo e Silva } \\
(2013)\end{array}$ & $\begin{array}{l}\text { Perfil dos artigos sobre } \\
\text { controladoria publicados em } \\
\text { periódicos nacionais de } \\
\text { contabilidade }\end{array}$ & $\begin{array}{l}\text { Identificar e analisar o perfil dos artigos sobre } \\
\text { controladoria publicados nos periódicos de } \\
\text { contabilidade que utilizam o SEER. }\end{array}$ \\
\hline $\begin{array}{l}\text { Wright, Callado e } \\
\text { Melo (2013) }\end{array}$ & $\begin{array}{c}\text { As funções da controladoria no } \\
\text { setor público: a percepção de } \\
\text { quem faz a Controladoria Geral } \\
\text { da União }\end{array}$ & $\begin{array}{l}\text { Descrever as funções de controladoria exercidas } \\
\text { pelos servidores da Controladoria Geral da União, } \\
\text { estabelecendo relações com a literatura. }\end{array}$ \\
\hline $\begin{array}{l}\text { Beuren e Zonatto } \\
\text { (2014) }\end{array}$ & $\begin{array}{c}\text { Perfil dos artigos sobre controle } \\
\text { interno no setor público em } \\
\text { periódicos nacionais e } \\
\text { internacionais }\end{array}$ & $\begin{array}{l}\text { Analisar o perfil de artigos sobre controle interno no } \\
\text { setor público, publicados em periódicos nacionais e } \\
\text { internacionais indexados na base de dados Scopus. }\end{array}$ \\
\hline $\begin{array}{c}\text { Silva, } \\
\text { Carneiro e } \\
\text { Ramos (2015) }\end{array}$ & $\begin{array}{l}\text { Controladoria no setor público: } \\
\text { uma comparação entre as leis } \\
\text { de criação em quatro dos } \\
\text { maiores municípios de } \\
\text { Rondônia e a literatura }\end{array}$ & $\begin{array}{l}\text { Verificar se as funções desempenhadas pelas } \\
\text { controladorias municipais de Rondônia estão de } \\
\text { acordo com as funções definidas na literatura. }\end{array}$ \\
\hline $\begin{array}{l}\text { Araújo, Libonati, } \\
\text { Miranda e Ramos } \\
\text { (2016) }\end{array}$ & $\begin{array}{l}\text { Unidades de controle interno } \\
\text { dos municípios brasileiros: } \\
\text { análise sob a ótica do COSO II }\end{array}$ & $\begin{array}{c}\text { Analisar quais são as constatações existentes nos } \\
\text { relatórios que evidenciam as ações de controle de } \\
\text { municípios, executadas em seu ambiente interno } \\
\text { (órgãos administrativos ou departamentos internos), } \\
\text { para verificar como estas ações relacionam-se com } \\
\text { a estrutura conceitual do COSO II. }\end{array}$ \\
\hline
\end{tabular}


Importância atribuída pelos Gestores às funções de Controladoria nas Prefeituras Municipais da Associação dos Municípios da Zona de Produção do Rio Grande do Sul

Natália da Silva Schio, Rodney Wernke, Antônio Zanin

\begin{tabular}{|c|c|c|}
\hline $\begin{array}{c}\text { Assis, } \\
\text { Silva e } \\
\text { Catapan (2016) }\end{array}$ & $\begin{array}{l}\text { As funções da controladoria e } \\
\text { sua aplicabilidade na } \\
\text { administração pública: uma } \\
\text { análise da gestão dos órgãos } \\
\text { de controle }\end{array}$ & $\begin{array}{l}\text { Avaliar se as práticas das Controladorias } \\
\text { apresentam o desempenho defendido } \\
\text { conceitualmente. }\end{array}$ \\
\hline $\begin{array}{c}\text { Cruz, } \\
\text { Silva e } \\
\text { Spinelli }(2016)\end{array}$ & $\begin{array}{l}\text { O papel das controladorias } \\
\text { locais no cumprimento da Lei } \\
\text { de Acesso à Informação pelos } \\
\text { municípios brasileiros }\end{array}$ & $\begin{array}{c}\text { Avaliar se a presença de uma controladoria na } \\
\text { estrutura organizacional de um munícipio brasileiro } \\
\text { tem surtido efeito quanto à promoção da } \\
\text { transparência municipal e ao monitoramento da Lei } \\
\text { de Acesso à Informação. }\end{array}$ \\
\hline $\begin{array}{l}\text { Fernandes e } \\
\text { Galvão (2016) }\end{array}$ & $\begin{array}{l}\text { A Controladoria como } \\
\text { ferramenta de gestão nas micro } \\
\text { e pequenas empresas: um } \\
\text { estudo da viabilidade e da } \\
\text { relação custo-benefício }\end{array}$ & $\begin{array}{l}\text { Refletir sobre o uso da controladoria como } \\
\text { ferramenta de gestão nas micro e pequenas } \\
\text { empresas (MPEs), baseada em informações } \\
\text { contidas em sites e em várias publicações. }\end{array}$ \\
\hline Galvão (2016) & $\begin{array}{l}\text { A implantação do sistema de } \\
\text { controle interno em órgãos } \\
\text { públicos como tecnologia de } \\
\text { redução de conflitos de } \\
\text { Agência } \\
\text { Pública/Governamental }\end{array}$ & $\begin{array}{l}\text { Demonstrar a importância da implantação de um } \\
\text { sistema de controle interno em órgãos públicos, não } \\
\text { só para o atendimento das exigências legais, mas } \\
\text { para se definir uma tecnologia de gestão capaz de } \\
\text { reduzir conflitos de interesse entre o governo e a } \\
\text { sociedade. }\end{array}$ \\
\hline $\begin{array}{c}\text { Henrique, } \\
\text { Chagas, } \\
\text { Guimarães e Leal } \\
\text { Jr. (2016) }\end{array}$ & $\begin{array}{l}\text { Análise da sistemática de } \\
\text { controle interno do município } \\
\text { de Três Rios }\end{array}$ & $\begin{array}{l}\text { Compreender o sistema de controle interno da } \\
\text { administração pública municipal de Três Rios. }\end{array}$ \\
\hline $\begin{array}{l}\text { Bonetti, Wernke } \\
\text { e Zanin (2017) }\end{array}$ & $\begin{array}{c}\text { Funções exercidas pela } \\
\text { controladoria das prefeituras } \\
\text { municipais do sudoeste do } \\
\text { Paraná }\end{array}$ & $\begin{array}{c}\text { Identificar as funções de controladoria exercidas } \\
\text { pelos Controllers municipais para compará-las com } \\
\text { aquelas mais mencionadas na literatura. }\end{array}$ \\
\hline $\begin{array}{l}\text { Souza, } \\
\text { Souto e } \\
\text { Nicolau }(2017)\end{array}$ & $\begin{array}{l}\text { Em um mundo de incertezas: } \\
\text { um survey sobre controle } \\
\text { interno em uma perspectiva } \\
\text { pública e privada }\end{array}$ & $\begin{array}{c}\text { Identificar como as organizações públicas e privadas } \\
\text { têm implementado o conceito e as dimensões } \\
\text { centrais do controle interno e quais os desafios } \\
\text { envolvidos neste processo a partir da visão dos } \\
\text { atores organizacionais. } \\
\end{array}$ \\
\hline
\end{tabular}

Figura 1. Pesquisas anteriores com foco nas funções de controladoria

Fonte: Elaborada pelos autores.

Ao se considerar os artigos elencados na Figura 1, bem como a diferença existente entre "práticas" e "funções" de controladoria, verifica-se que apenas as pesquisas de Wright, Callado e Melo (2013) e Bonetti et al. (2017) tratam especificamente sobre as funções de controladoria no contexto da administração pública. Contudo, somente esta última discorre acerca das funções de controladoria no 
Importância atribuída pelos Gestores às funções de Controladoria nas Prefeituras Municipais da Associação dos Municípios da Zona de Produção do Rio Grande do Sul Natália da Silva Schio, Rodney Wernke, Antônio Zanin

âmbito dos municípios brasileiros, mas visa conhecer a opinião dos controllers a respeito das atividades que os mesmos exercem nas prefeituras.

Assim, percebe-se uma lacuna de pesquisa quanto à relevância das funções de controladoria sob a perspectiva dos gestores das prefeituras municipais, ou seja, a pesquisa precedente relacionada com as funções prioriza a visão dos controllers municipais acerca da controladoria, sem abordar como os gestores que recebem as informações oriundas valorizam as funções da controladoria no contexto dos municípios abrangidos. Nesse rumo, esta pesquisa almeja contribuir para minimizar esse aspecto, conforme descrito nas próximas seções.

\section{PROCEDIMENTOS METODOLÓGICOS}

Para a elaboração deste trabalho, utilizou-se a pesquisa descritiva, com abordagem quantitativa dos dados. De acordo com Rauen (2015, p. 157), este tipo de pesquisa é denominado como "levantamento de dados, de sondagem ou survey e consiste na solicitação de informações a um grupo estatisticamente significativo de pessoas para posterior análise quantitativa, recorrendo-se a técnicas de pesquisa de campo".

Richardson (1999) conceitua a pesquisa quantitativa como "o emprego da quantificação, tanto nas modalidades de coleta de informações quanto no tratamento delas por meio de técnicas estatísticas". Aduz, ainda, que a abordagem quantitativa é utilizada geralmente em estudos descritivos, caracterizando-se pelo emprego de técnicas estatísticas na coleta e ou no tratamento dos dados com o intuito de evitar distorções de análise e interpretação. Além disso, numa pesquisa quantitativa Castellan (2010), defende que o pesquisador assume posição de independência em relação ao que é pesquisado e salienta que a análise estatística tem por finalidade a descrição das características do objeto de estudo. 
Importância atribuída pelos Gestores às funções de Controladoria nas Prefeituras Municipais da Associação dos Municípios da Zona de Produção do Rio Grande do Sul Natália da Silva Schio, Rodney Wernke, Antônio Zanin

Nessa direção, a pesquisa survey pode ser caracterizada como a obtenção de dados ou informações sobre características, ações ou opiniões de um determinado grupo de pessoas pré-estabelecidas para o estudo, por meio de um instrumento de pesquisa que normalmente tem a forma de questionário. $\mathrm{E} O$ interesse da pesquisa survey reside em reproduzir descrições quantitativas de uma população, fazendo uso de um instrumento predefinido (Pinsonneault \& Kraemer, 1993).

\subsection{População e Amostra}

A população inicial do estudo em questão foi composta pelos 43 municípios pertencentes à Associação dos Municípios da Zona de Produção do Rio Grande do Sul (AMZOP), que abrange as cidades de Alpestre, Ametista do Sul, Barra Funda, Boa Vista das Missões, Caiçara, Cerro Grande, Chapada, Constantina, Cristal do Sul, Dois Irmãos das Missões, Engenho Velho, Erval Seco, Frederico Westphalen, Gramados Loureiros, Iraí, Jaboticaba, Lajeado Bugre, Liberato Salzano, Nonoai, Nova Boa Vista, Novo Barreiro, Novo Tiradentes, Novo Xingú, Palmeira das Missões, Palmitinho, Pinhal, Pinheirinho do Vale, Planalto, Pontão, Rio dos Índios, Rodeio Bonito, Ronda Alta, Rondinha, Sagrada Família, São José das Missões, São Pedro das Missões, Sarandi, Seberi, Taquaruçu do Sul, Três Palmeiras, Trindade do Sul, Vicente Dutra e Vista Alegre.

A referida associação tem a finalidade de proporcionar a integração política de seus membros, prestando assistência técnica e desenvolvendo estudos relativos à organização da administração pública dos municípios vinculados, especialmente no tocante à reestruturação dos serviços e aperfeiçoando do trabalho de servidores e de prestadores terceirizados (AMZOP, 2018).

Quanto à opção por circunscrever a abrangência aos municípios da AMZOP, esta foi motivada pela necessidade de delimitação da pesquisa, que para ser exequível, deve se restringir a determinado alvo, sob pena de perder a consistência (Rauen, 2015), e pela maior facilidade de acesso aos dados. Por isso, optou-se por limitar o 
Importância atribuída pelos Gestores às funções de Controladoria nas Prefeituras Municipais da Associação dos Municípios da Zona de Produção do Rio Grande do Sul Natália da Silva Schio, Rodney Wernke, Antônio Zanin

estudo às cidades dessa associação de municípios, que possuíam 279.644 habitantes em 2018, segundo a estimativa populacional obtida no site do Instituto Brasileiro de Geografia e Estatística - IBGE (2018).

\subsection{Coleta de Dados}

Os dados desta pesquisa foram coligidos por intermédio de um questionário especialmente elaborado. Nesse rumo, Malhotra (2012) argumenta que o questionário pode ser idealizado com três objetivos: (1) transformar as informações desejadas em um conjunto de questões que os respondentes tenham capacidade de responder; (2) motivar o respondente objetivando que o mesmo se envolva com a pesquisa para responder cautelosamente o questionário; e (3) ter a capacidade de minimizar possíveis erros nas respostas.

Além disso, de acordo com Aaker, Kumar e Day (2001), a construção de um questionário é considerada uma "arte imperfeita", pois não existem procedimentos certeiros que garantam que seus objetivos de mensuração sejam alcançados de forma qualificada. Contudo, alguns fatores, como bom senso e experiência do pesquisador, são relevantes para driblar os possíveis erros.

$\mathrm{Na}$ pesquisa em tela, primeiramente foi realizado contato telefônico com o presidente da AMZOP solicitando-se permissão para a aplicação do questionário. Diante da aprovação, o questionário foi aplicado numa reunião ocorrida no município de Iraí (RS), em 11 de junho de 2018. Estavam presentes 37 representantes municipais (prefeitos, vice-prefeitos, secretários e assessores jurídicos), mas somente 33 concordaram em participar do estudo. Desses, após exame dos questionários respondidos, foram descartadas três participações, o que acarretou o número final de 30 municípios de um total de 43 da região citada (69,77\% do total).

O questionário elaborado foi composto por duas seções. A primeira trazia questionamentos relativos às características dos respondentes (como cargo ocupado, tempo de atuação no referido cargo, grau de escolaridade e área de formação 
Importância atribuída pelos Gestores às funções de Controladoria nas Prefeituras Municipais da Associação dos Municípios da Zona de Produção do Rio Grande do Sul Natália da Silva Schio, Rodney Wernke, Antônio Zanin

acadêmica). A segunda parte do instrumento utilizado abrangia as oito funções da controladoria descritas por Borinelli (2006), ou seja: contábil, gerencial-estratégica, custos, tributária, proteção e controle dos ativos, controle interno, controle de riscos e gestão da informação. Nessa direção, foram apresentadas 29 perguntas acerca das funções selecionadas, subdivididas em quantidades distintas conforme o tipo de função, ou seja, com no máximo sete questões (para a Função Tributária) e, no mínimo, uma pergunta (para a Função de Controle Interno). Em todas essas indagações, havia a possibilidade de o respondente escolher respostas numa escala Likert de cinco pontos que ia de "1-Irrelevante" até "5-Muito importante".

\subsection{Procedimento de Análise dos Dados}

Com a finalidade de verificar as diferenças das intensidades dos níveis de percepção dos gestores quanto às funções exercidas pelo setor de controladoria em cada prefeitura, foram considerados somente as variáveis "número de habitantes" do município e "graduação do gestor" e "cargo ocupado" pelos gestores.

Para tanto, utilizou-se o teste estatístico Kruskal-Wallis, com o objetivo de testar as seguintes hipóteses:

a) Quanto ao nível da importância atribuída pelos gestores às funções de controladoria, independentemente do número de habitantes:

- H0(nula): a média do nível da importância atribuída pelos gestores é igual nas oito funções, independentemente do número de habitantes;

- H1: a média do nível da importância atribuída pelos gestores é diferente nas oito funções, independentemente do número de habitantes.

b) Quanto ao nível da importância atribuída pelos gestores às funções de controladoria, independentemente da área de graduação dos gestores:

- H0(nula): a média do nível da importância atribuída pelos gestores é igual nas oito funções, independentemente da área de graduação; 
Importância atribuída pelos Gestores às funções de Controladoria nas Prefeituras Municipais da Associação dos Municípios da Zona de Produção do Rio Grande do Sul Natália da Silva Schio, Rodney Wernke, Antônio Zanin

- H1: a média do nível de importância atribuída pelos gestores é diferente nas oito funções, independentemente da área de graduação.

c) Quanto ao nível da importância atribuída pelos gestores às funções de controladoria, independentemente do cargo ocupado pelos gestores:

- H0(nula): a média do nível da importância atribuída pelos gestores é igual nas oito funções, independentemente do cargo ocupado;

- H1: a média do nível de importância atribuída pelos gestores é diferente nas oito funções, independentemente do cargo ocupado.

Levine, Berenson e Stephan (2000) esclarecem que o teste Kruskal-Wallis analisa a significância das diferenças observadas entre três ou mais grupos de dados que são analisados simultaneamente. No caso desta pesquisa, as prefeituras foram segregadas de acordo com o número de habitantes de cada município e formaram três segmentos: até 5.000 habitantes, entre 5.001 e 10.000 habitantes e mais de 10.000 habitantes.

Cabe ressaltar que o Kruskal-Wallis é um teste não paramétrico que deve ser utilizado "na análise do fato de $\mathrm{K}(\mathrm{K}>2)$ amostras independentes serem originárias ou não de populações com médias iguais, podendo ser aplicado também com variáveis intercalares ou ordinais" (Bruni, 2012). Nesse rumo, o citado autor relata que os resultados oriundos deste teste devem ser interpretados da seguinte forma:

1) Se "Sig > 0,05": não se pode rejeitar a hipótese nula (H0), aceitando-se o fato de que as médias populacionais dos $\mathrm{K}$ grupos sejam iguais;

2) Se "Sig < 0,05": rejeita-se a hipótese nula ( $\mathrm{H} 0)$, aceitando-se o fato de existir pelo menos um par de médias populacionais diferentes.

Ainda convém salientar que, para a realização dos procedimentos estatísticos mencionados, foi utilizado o software Statistical Package for Social Sciences (SPSS). 
Importância atribuída pelos Gestores às funções de Controladoria nas Prefeituras Municipais da Associação dos Municípios da Zona de Produção do Rio Grande do Sul Natália da Silva Schio, Rodney Wernke, Antônio Zanin

\section{APRESENTAÇÃO E DISCUSSÃO DOS RESULTADOS}

Nas próximas seções, são evidenciados os resultados oriundos e mencionadas as análises efetuadas a partir dos dados coletados.

\subsection{Perfil da área de controladoria dos municípios abrangidos}

Quanto à caracterização dos respondentes que participaram da pesquisa, 66,4\% ocupavam o cargo de Prefeito Municipal (vinte participantes). Além disso, quatro respondentes exerciam o cargo de Vice-Prefeito Municipal, quatro eram secretários municipais e dois eram assessores jurídicos.

No que tange ao tempo de atuação no cargo citado, 36,7\% dos respondentes estão no cargo há menos de um ano; 13,3\% entre 1 e 2 anos; 26,7\% entre 3,1 e 5 anos; $10 \%$ entre 5,1 e 8 anos e 13,3\% estão atuando no cargo descrito há mais de 8 anos.

Acerca do nível de escolaridade dos gestores, 26,7\% declararam ter escolaridade até o Segundo Grau completo, enquanto 6,7\% dos gestores alegaram estar cursando Ensino Superior e 43,3\% afirmaram ter nível superior completo. Além disso, apenas um gestor (3,3\%) mencionou que está cursando pós-graduação e seis respondentes (20\%) aduziram ter pós-graduação completa.

Daqueles que concluíram ou estão estudando em curso superior (50\% do total de respondentes), somente $13,3 \%$ mencionaram não terem estudado nas áreas de Contabilidade, Administração e Direito. Quanto aos gestores que estão cursando ou já concluíram a pós-graduação $(23,3 \%$ do total de respondentes), as titulações estão relacionadas às áreas de Contabilidade (6,7\%), Administração ou assemelhados (3,3\%), Direito ou assemelhados (3,3\%), e 10\% optaram pela opção "Outros". 
Importância atribuída pelos Gestores às funções de Controladoria nas Prefeituras Municipais da Associação dos Municípios da Zona de Produção do Rio Grande do Sul Natália da Silva Schio, Rodney Wernke, Antônio Zanin

\subsection{Nível de importância das funções considerando o número de habitantes}

Para analisar estatisticamente os dados obtidos acerca da importância que os gestores participantes atribuíram às funções de controladoria executada pelos controllers municipais, inicialmente foram avaliadas as respostas segregadas quanto ao número de habitantes de cada cidade.

Considerando que o número de respondentes é inferior ou igual a 30, foi realizado o teste de normalidade Kolmogorov-Sminorv, que verificou a não normalidade dos dados, conforme preconizado por Bruni (2012). Destarte, foi empregado o teste não paramétrico Kruskal-Wallis, considerando os três grupos de municípios segregados pelo número de habitantes, cujos resultados mais relevantes estão dispostos na Tabela 1 e abrangem também as médias de cada uma das 29 questões apresentadas, bem como a média apurada por tipo de função.

Tabela 1

Importância das Funções de Controladoria- Kruskal-Wallis test

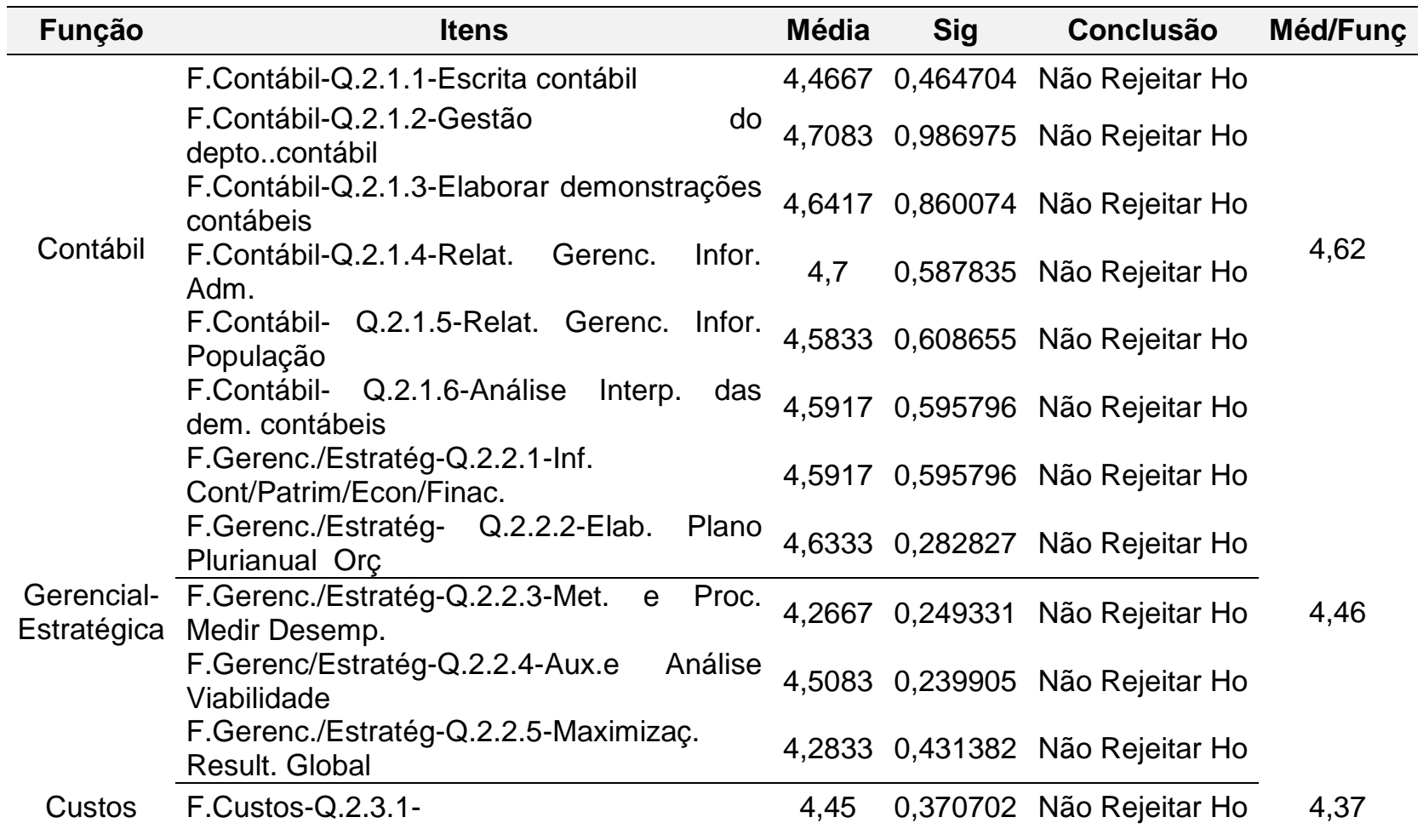


Importância atribuída pelos Gestores às funções de Controladoria nas Prefeituras Municipais da Associação dos Municípios da Zona de Produção do Rio Grande do Sul Natália da Silva Schio, Rodney Wernke, Antônio Zanin

\begin{tabular}{|c|c|c|c|c|}
\hline & eg./Mens/Cont/Análise/Aval/Custos & & & \\
\hline & 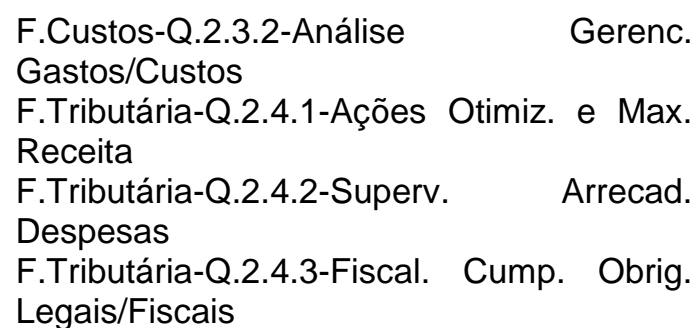 & $\begin{array}{r}4,2833 \\
4,7583 \\
4,85 \\
4,5833\end{array}$ & 0,874646 & Não Rejeitar Ho \\
\hline Tributária & F.Tributária-Q.2.4.4-Planej.Tributário & 4,3417 & 0,689792 & Não Rejeitar Ho \\
\hline & $\begin{array}{l}\text { F.Tributária-Q.2.4.5-Monit. Planej } \quad \text { x } \\
\text { Realizado }\end{array}$ & 4,3083 & 0,252742 & Não Rejeitar Ho \\
\hline & $\begin{array}{l}\text { F.Tributária-Q.2.4.6- Legal. Execução } \\
\text { Desp. Orçament. }\end{array}$ & 4,7167 & 0,496311 & Não Rejeitar Ho \\
\hline Proteção e & $\begin{array}{l}\text { F.Tributária-Q.2.4.7-Coord./Asses./Coord. } \\
\text { Planej. e Orç. } \\
\text { F.Proteç. Cont.Ativos-Q.2.5.1-Contrat e } \\
\text { Cont. de Segur. }\end{array}$ & $\begin{array}{c}4,5167 \\
4,2\end{array}$ & $\begin{array}{l}0,253075 \\
0,015579\end{array}$ & $\begin{array}{l}\text { Não Rejeitar Ho } \\
\underline{\text { Rejeitar Ho }}\end{array}$ \\
\hline $\begin{array}{l}\text { Controle } \\
\text { de }\end{array}$ & $\begin{array}{l}\text { F.Proteç.Cont. Ativos-Q.2.5.2-Asseg. } \\
\text { audit.de licitações }\end{array}$ & 4,3667 & 0,029363 & Rejeitar Ho \\
\hline Ativos & $\begin{array}{l}\text { F.Proteç. Cont.Ativos-Q.2.5.3-Reg/Contr } \\
\text { Bens Patrim. }\end{array}$ & 4,4083 & 0,483642 & Não Rejeitar Ho \\
\hline $\begin{array}{l}\text { Contr. } \\
\text { Interno }\end{array}$ & $\begin{array}{l}\text { F.Cont. Interno-Q.2.6.1-Monit.Sist. Cont. } \\
\text { Interno }\end{array}$ & 4,7083 & 0,94889 & Não Rejeitar Ho \\
\hline Controle & $\begin{array}{l}\text { F.Contr. Riscos-Q.2.7.1-Eficiência na Exec. } \\
\text { da Despesa }\end{array}$ & 4,4917 & 0,998834 & Não Rejeitar Ho \\
\hline de Riscos & $\begin{array}{l}\text { F.Contr. Riscos- Q.2.7.2-Acomp./Realiz da } \\
\text { Auditoria }\end{array}$ & 4,7417 & 0,991118 & Não Rejeitar Ho \\
\hline & $\begin{array}{l}\text { F.Contr. Riscos-Q.2.7.3-Ident./Cont. Riscos } \\
\text { a Ent. }\end{array}$ & 4,3667 & 0,745335 & Não Rejeitar Ho \\
\hline & $\begin{array}{l}\text { F.Gestão do Info-Q.2.8.1-Modelos de } \\
\text { Inform. }\end{array}$ & 4,2417 & 0,695545 & Não F \\
\hline $\ln$ & $\begin{array}{l}\text { F.Gestão do Info-Q.2.8.2-Gest. Sist. de } \\
\text { Informação }\end{array}$ & 4,45 & 0,980265 & Não Rejeitar Ho \\
\hline
\end{tabular}

Nota. Fonte: Elaborada pelos autores.

Para analisar os resultados da Tabela 1, foi considerado o exposto por Bruni (2012), ou seja: se "Sig > 0,05", não cabe rejeitar a hipótese nula (visto que as médias dos grupos são iguais); e se "Sig $<0,05$ ", é pertinente rejeitar a hipótese nula, pois existe ao menos um par de médias populacionais diferentes.

Portanto, cabe concluir que, nas 29 questões analisadas, 27 funções possuem médias de importância semelhantes entre os grupos de municípios pequenos, médios e grandes. Com isso, não cabe aceitar a rejeição da Hipótese Ho (nula) e é plausível 
Importância atribuída pelos Gestores às funções de Controladoria nas Prefeituras Municipais da Associação dos Municípios da Zona de Produção do Rio Grande do Sul Natália da Silva Schio, Rodney Wernke, Antônio Zanin

afirmar que a maioria das funções de controladoria possui o mesmo nível de importância nos municípios estudados.

Por outro lado, nas duas questões relacionadas à função de Proteção e Controle de Ativos (Questões "2.5.1" e "2.5.2") é interessante a aceitação da hipótese alternativa (H1), visto que a média dos três grupos relacionados com a quantidade de habitantes nessas funções é diferente. Esta conclusão também foi confirmada por outro output do SPSS alusivo ao ranqueamento das médias (Mean Rank), de vez que nessas duas questões comparou-se a diferença entre a maior e a menor média, e os resultados foram 11,91 pontos para a questão "2.5.1" e 9,64 pontos na questão "2.5.2".

Neste ponto, cabe salientar que a discussão desses resultados e o cotejamento com estudos anteriores (e também os relacionados com as outras duas perspectivas adotadas e abordadas nas próximas seções) são evidenciados na seção 4.5.

\subsection{Nível de importância das funções considerando a graduação dos gestores}

No que tange ao nível de importância das funções de controladoria, considerando a variável de agrupamento "graduação dos gestores", o teste KruskalWallis apurou as médias existentes nos cinco grupos, concluindo pela aceitação ou rejeição da hipótese nula (Ho), conforme demonstrado na Tabela 2. 
Importância atribuída pelos Gestores às funções de Controladoria nas Prefeituras Municipais da Associação dos Municípios da Zona de Produção do Rio Grande do Sul Natália da Silva Schio, Rodney Wernke, Antônio Zanin

Tabela 2

Teste Kruskal-Wallis (importância das funções versus graduação do gestor)

\begin{tabular}{|c|c|c|c|}
\hline Itens & Qui-quadrado & Sig & Conclusão \\
\hline F.Contábil-Q.2.1.1-Escrita contábil & 8,35 & 0,079565 & Não Rejeitar Ho \\
\hline F.Contábil-Q.2.1.2-Gestão do depto. contábil & 4,545 & 0,337214 & Não Rejeitar Ho \\
\hline F.Contábil-Q.2.1.3-Elaborar demonstrações contábeis & 2,877 & 0,578634 & Não Rejeitar Ho \\
\hline F.Contábil-Q.2.1.4-Relat. Gerenc. Infor. Adm. & 0,691 & 0,952386 & Não Rejeitar Ho \\
\hline F.Contábil- Q.2.1.5-Relat. Gerenc. Infor. População & 1,241 & 0,871366 & Não Rejeitar Ho \\
\hline F.Contábil- Q.2.1.6-Análise Interp. das dem. contábeis & 1,894 & 0,755217 & Não Rejeitar Ho \\
\hline F.Gerenc/Estratég-Q.2.2.1-Inf .Cont/Patrim/Econ/Financ. & 1,894 & 0,755217 & Não Rejeitar Ho \\
\hline F.Gerenc/Estratég- Q.2.2.2-Elab. Plano Plurianual Orç. & 4,456 & 0,347838 & Não Rejeitar Ho \\
\hline F.Gerenc/Estratég-Q.2.2.3-Met. e Proc. Medir Desemp. & 2,155 & 0,70724 & Não Rejeitar Ho \\
\hline F.Gerenc/Estratég-Q.2.2.4-Aux. e Análise Viabilidade & 4,485 & 0,344293 & Não Rejeitar Ho \\
\hline F.Gerenc/Estratég-Q.2.2.5-Maximização Result. Global & 8,277 & 0,081937 & Não Rejeitar Ho \\
\hline F.Custos-Q.2.3.1-Reg./Mens./Cont./Análise/Aval./Custos & 6,609 & 0,158041 & Não Rejeitar Ho \\
\hline F.Custos-Q.2.3.2-Análise Gerenc. Gastos/Custos & 8,277 & 0,081937 & Não Rejeitar Ho \\
\hline F.Tributária-Q.2.4.1-Ações Otimiz. e Max. Receita & 3,226 & 0,520802 & Não Rejeitar Ho \\
\hline F.Tributária-Q.2.4.2-Superv. Arrecad. Despesas & 6,378 & 0,172643 & Não Rejeitar Ho \\
\hline F.Tributária-Q.2.4.3-Fiscal.Cump. Obrig. Legais/Fiscais & 3,427 & 0,489129 & Não Rejeitar Ho \\
\hline F.Tributária-Q.2.4.4-Planej.Tributário & 2,117 & 0,714245 & Não Rejeitar Ho \\
\hline F.Tributária-Q.2.4.5-Monit. Planej. x Realizado & 1,284 & 0,864014 & Não Rejeitar Ho \\
\hline F.Tributária-Q.2.4.6- Legal. Execução Desp. Orçament. & 5,304 & 0,257536 & Não Rejeitar Ho \\
\hline F.Tributária-Q.2.4.7-Coord/Asses/Coord Planej. e Orç. & 4,062 & 0,397734 & Não Rejeitar Ho \\
\hline F.Proteç.Cont Ativos-Q.2.5.1-Contrat e Cont de Seguros & 6,39 & 0,171849 & Não Rejeitar Ho \\
\hline F.Proteç.Cont Ativos-Q.2.5.2-Asseg. audit. de licitações & 3,499 & 0,478014 & Não Rejeitar Ho \\
\hline F.Proteç.Cont Ativos-Q.2.5.3-Reg/Contr Bens Patrim. & 4,156 & 0,385295 & Não Rejeitar Ho \\
\hline F.Cont.Interno-Q.2.6.1-Monit.Sist.Cont.Interno & 3,017 & 0,554916 & Não Rejeitar Ho \\
\hline F.Contr.Riscos-Q.2.7.1-Eficiência na Exec. da Despesa & 7,766 & 0,100532 & Não Rejeitar Ho \\
\hline F.Contr.Riscos-Q.2.7.2-Acomp./Realiz. da Auditoria & 10,22 & 0,036874 & $\underline{\text { Rejeitar Ho }}$ \\
\hline F.Contr.Riscos-Q.2.7.3-Ident./Cont. Riscos a Ent. & 5,521 & 0,237913 & Não Rejeitar Ho \\
\hline F.Gestão do Info-Q.2.8.1-Modelos de Inform. & 5,957 & 0,202361 & Não Rejeitar Ho \\
\hline F.Gestão do Info-Q.2.8.2-Gest. Sist. de Informação & 2,874 & 0,579211 & Não Rejeitar Ho \\
\hline
\end{tabular}

Nota. Fonte: Elaborada pelos autores.

Pela verificação da significância (coluna "Sig" da Tabela 2), constatou-se que apenas uma das questões (pertencente à função Controle de Riscos) foi rejeitada, se 
Importância atribuída pelos Gestores às funções de Controladoria nas Prefeituras Municipais da Associação dos Municípios da Zona de Produção do Rio Grande do Sul Natália da Silva Schio, Rodney Wernke, Antônio Zanin

considerada a hipótese nula (Ho). Neste caso, para a "F.Contr.Riscos-Q.2.7.2Acomp/Realiz da Auditoria", apurou-se que "Sig. < 0,05"; portanto, a média do nível de importância atribuída a essa função é diferente entre os grupos formados pelo tipo de graduação dos respondentes. Essas conclusões também podem ser fundamentadas pelo ranqueamento das médias (Mean Rank), em que a diferença da maior para a menor média divergiu em 9,5 pontos entre os grupos no âmbito desta questão especificamente.

Nas demais 28 questões relativas às funções de controladoria não cabe rejeitar a hipótese nula $(\mathrm{Ho})$, visto que os valores da coluna "Sig" da Tabela 2 são maiores que 0,05 ("Sig >0,05"). Destarte, considera-se que as médias dos níveis da importância atribuída pelos gestores às funções destas questões são iguais entre os grupos relacionados aos cursos de graduação dos participantes.

\subsection{Nível de importância das funções considerando o cargo dos gestores}

A última variável de agrupamento analisada foi o "cargo ocupado" pelos gestores, e o teste Kruskal-Wallis apurou as médias entre os grupos deste foco como deslindado, de forma detalhada, na Tabela 3. 
Importância atribuída pelos Gestores às funções de Controladoria nas Prefeituras Municipais da Associação dos Municípios da Zona de Produção do Rio Grande do Sul Natália da Silva Schio, Rodney Wernke, Antônio Zanin

Tabela 3

Teste Kruskal-Wallis (importância das funções versus cargo ocupado pelo gestor)

\begin{tabular}{|c|c|c|c|}
\hline Itens & Qui-quadrado & Sig & Conclusão \\
\hline F.Contábil-Q.2.1.1-Escrita contábil & 5,956 & 0,113774 & Não Rejeitar Ho \\
\hline F.Contábil-Q.2.1.2-Gestão do Depto. Contábil & 1,856 & 0,602828 & Não Rejeitar Ho \\
\hline F.Contábil-Q.2.1.3-Elaborar demonstrações contábeis & 1,114 & 0,773796 & Não Rejeitar Ho \\
\hline F.Contábil-Q.2.1.4-Relat.Gerenc.Infor. Adm. & 0,386 & 0,943156 & Não Rejeitar Ho \\
\hline F.Contábil- Q.2.1.5-Relat. Gerenc. Infor. População & 1,718 & 0,632873 & Não Rejeitar Ho \\
\hline F.Contábil- Q.2.1.6-Análise e Interp. das Dem. Contábeis & 2,153 & 0,541257 & Não Rejeitar Ho \\
\hline F.Gerenc/Estratég-Q.2.2.1-Inf. Cont./Patrim./Econ./Financ. & 2,153 & 0,541257 & Não Rejeitar Ho \\
\hline F.Gerenc/Estratég- Q.2.2.2-Elab. Plano Plurianual Orç. & 2,757 & 0,430699 & Não Rejeitar Ho \\
\hline F.Gerenc/Estratég-Q.2.2.3-Met.e Proc. Medir Desemp. & 0,286 & 0,962696 & Não Rejeitar Ho \\
\hline F.Gerenc/Estratég-Q.2.2.4-Aux. e Análise Viabilidade & 2,114 & 0,549186 & Não Rejeitar Ho \\
\hline F.Gerenc/Estratég-Q.2.2.5-Maximização Result. Global & 5,674 & 0,128621 & Não Rejeitar Ho \\
\hline F.Custos-Q.2.3.1-Reg./Mens./Cont./Análise/Aval./Custos & 2,618 & 0,454381 & Não Rejeitar Ho \\
\hline F.Custos-Q.2.3.2-Análise e Gerenc. Gastos/Custos & 5,674 & 0,128621 & Não Rejeitar Ho \\
\hline F.Tributária-Q.2.4.1-Ações Otimiz e Max. Receita & 1,518 & 0,678079 & Não Rejeitar Ho \\
\hline F.Tributária-Q.2.4.2-Superv. Arrecad. Despesas & 3,958 & 0,265989 & Não Rejeitar Ho \\
\hline F.Tributária-Q.2.4.3-Fiscal. Cump. Obrig. Legais/Fiscais & 10,625 & 0,013935 & Rejeitar Ho \\
\hline F.Tributária-Q.2.4.4-Planej.Tributário & 1,305 & 0,727879 & Não Rejeitar Ho \\
\hline F.Tributária-Q.2.4.5-Monit. Planej. x Realizado & 1,693 & 0,638518 & Não Rejeitar Ho \\
\hline F.Tributária-Q.2.4.6- Legal/Execução Desp. Orçament. & 6,387 & 0,094219 & Não Rejeitar Ho \\
\hline F.Tributária-Q.2.4.7-Coord./Asses./Coord. Planej. e Orç. & 4,691 & 0,195912 & Não Rejeitar Ho \\
\hline F.Proteç.Cont Ativos-Q.2.5.1-Contrat e Cont. de Seguros & 2,422 & 0,489499 & Não Rejeitar Ho \\
\hline F.Proteç.Cont Ativos-Q.2.5.2-Asseg. audit. de licitações & 3,278 & 0,3507 & Não Rejeitar Ho \\
\hline F.Proteç.Cont Ativos-Q.2.5.3-Reg./Contr. Bens Patrim. & 2,117 & 0,548478 & Não Rejeitar Ho \\
\hline F.Cont.Interno-Q.2.6.1-Monit. Sist. Cont. Interno & 6,068 & 0,108342 & Não Rejeitar Ho \\
\hline F.Contr.Riscos-Q.2.7.1-Eficiência na Exec. da Despesa & 1,282 & 0,7335 & Não Rejeitar Ho \\
\hline F.Contr.Riscos- Q.2.7.2-Acomp./Realiz. da Auditoria & 1,692 & 0,638614 & Não Rejeitar Ho \\
\hline F.Contr.Riscos-Q.2.7.3-Ident./Cont. Riscos_à Ent. & 0,768 & 0,857074 & Não Rejeitar Ho \\
\hline F.Gestão do Info-Q.2.8.1-Modelos de Inform. & 1,699 & 0,637241 & Não Rejeitar Ho \\
\hline F.Gestão do Info-Q.2.8.2-Gest. Sist. de Informação & 1,813 & 0,612112 & Não Rejeitar Ho \\
\hline
\end{tabular}

Nota. Fonte: Elaborada pelos autores.

A partir dos valores da coluna "Sig" da Tabela 3, depreende-se que em apenas uma das questões ("F.Tributária-Q.2.4.3-Fiscal.Cump.Obrig.Legais/Fiscais") foi rejeitada a hipótese nula Ho (pois Sig < 0,05). Desse modo, é pertinente considerar que a média do nível da importância atribuída à atividade da função citada é diferente entre os grupos formados pelos cargos ocupados pelos gestores. Todavia, nas demais questões é cabível concluir que essas médias são iguais entre os grupos e, portanto, não cabe 
Importância atribuída pelos Gestores às funções de Controladoria nas Prefeituras Municipais da Associação dos Municípios da Zona de Produção do Rio Grande do Sul Natália da Silva Schio, Rodney Wernke, Antônio Zanin

rejeitar a hipótese nula (Ho) nessas outras 28 questões apresentadas aos respondentes.

\subsection{Discussão dos resultados e cotejamento com outras pesquisas}

Esta seção visa comentar e comparar os resultados deste estudo em relação aos das pesquisas com focos assemelhados mencionadas no Quadro 1, anteriormente apresentado.

No contexto empresarial, Fachini et al. (2010) concluíram que os respondentes atribuíram mais importância às funções de coordenação, assessoramento e consolidação dos processos de elaboração de planos empresariais, orçamentos e previsões. Além disso, apuraram que oito empresas atribuíram nota máxima (5) a todos os itens relacionados à função de custos, bem como deram notas elevadas (4 ou 5) às funções gerenciais estratégicas. Mesmo que tal estudo aborde empresas privadas e este esteja focado em prefeituras municipais, os resultados nesses aspectos se assemelharam, visto que a média da importância atribuída à função "custos" foi de 4,37 pontos e a função gerencial-estratégica foi de 4,46 pontos. Entretanto, foi identificada divergência no que concerne à pouca importância imputada às atividades da função tributária (registrar, apurar e controlar impostos, tributos e contribuições), enquanto que, no estudo ora relatado, a média atribuída a esta função foi de 4,58 pontos. Essa relevância maior no caso das prefeituras provavelmente está associada ao fato de que essas entidades priorizam fortemente o aspecto da arrecadação de tributos.

Por sua vez, Suzart et al. (2011) também chegaram a resultados que são assemelhados aos desta pesquisa. Nesse sentido, a função que mais se destacou naquele estudo é a de Controle Interno, uma peculiaridade que também foi percebida neste relato, em que a média de importância mais alta foi alcançada pelo grupo de perguntas relativas à função de controle interno (com 4,71 pontos). Além disso, os referidos autores também apuraram que as funções de "controle de ativos" e "tributária" eram pouco desempenhadas nos órgãos de controladoria pública brasileiros, enquanto 
Importância atribuída pelos Gestores às funções de Controladoria nas Prefeituras Municipais da Associação dos Municípios da Zona de Produção do Rio Grande do Sul Natália da Silva Schio, Rodney Wernke, Antônio Zanin

que, no presente trabalho, essas duas funções foram consideradas relevantes para os gestores indagados, atingindo médias 4,33 e 4,58 pontos, respectivamente.

Araújo et al. (2016) analisaram se as funções constantes nos relatórios emitidos pelas unidades de controle interno dos municípios brasileiros são desempenhadas em consonância com o coso II. No que concerne aos resultados atrelados aos procedimentos de controle e avaliação de risco, equivalentes nesta pesquisa às funções "Controle Interno" e "Controle de Riscos", os resultados também apresentaram médias elevadas e assemelharam-se aos deste estudo (onde atingiram 4,71 e 4,53 pontos, respectivamente).

Lunkes et al. (2009) pesquisaram as literaturas alemãs e americanas e concluíram que as funções de planejamento, controle e elaboração de relatórios eram as mais citadas na literatura americana e que, no contexto da Alemanha, se sobressaíam as funções de planejamento, controle e sistemas de informação. Neste estudo, a função de planejamento estava contemplada nas questões ligadas ao grupo da função Gerencial-Estratégica (onde havia perguntas acerca do planejamento e do Plano Plurianual). Destarte, esta atingiu média 4,46, o que significa que a prática mais presente na literatura americana é considerada também muito importante pelos gestores das prefeituras analisadas nesta pesquisa. Além disso, também foi dada importância elevada para a função Controle e Sistemas de Informação, o que se coaduna com a priorização identificada na literatura alemã.

Contudo, se consideradas somente as pesquisas com foco no serviço público, Wright, Callado e Melo (2013) estudaram as funções de controladoria utilizadas na Controladoria Geral da União (CGU) e identificaram que as mais observadas foram as de controle interno, promoção da transparência, estímulo ao controle social, suporte à gestão por meio de informações e elaboração de procedimentos e políticas de controle. Referidos autores relacionaram essas atividades com as funções de controle interno, controle de riscos e de gestão de informação, que neste estudo atingiram médias 4,70, 4,53 e 4,34, respectivamente. 
Importância atribuída pelos Gestores às funções de Controladoria nas Prefeituras Municipais da Associação dos Municípios da Zona de Produção do Rio Grande do Sul Natália da Silva Schio, Rodney Wernke, Antônio Zanin

Bonetti et al. (2017) investigaram as funções de controladoria exercida por controllers de municípios paranaenses e concluíram que as atuações mais frequentes relacionam-se às atividades ligadas às funções de "Proteção de Ativos" (25\% das respostas a respeito) e "Gerencial/estratégico" (com 23,33\%), seguidas pelas funções "Contábil", "Custos", "Tributária" e "Planejamento e Controle" (cada uma com 10\% do total das citações apuradas).

Porém, na presente pesquisa, somente a função "Proteção e Controle de Ativos" teve níveis de importância distintos entre os grupos de municípios, considerando-se o critério do número de habitantes; enquanto que as hipóteses relacionadas ao cargo e tipo de graduação dos gestores tiveram respostas médias semelhantes (confirmando a hipótese nula de igualdade entre os grupos pesquisados). Ainda, no que tange à função "Gerencial-estratégica", que obteve destaque no estudo de Bonetti et al. (2017), nesta pesquisa tal função teve nível igualitário de importância atribuído pelos gestores em todos os três ângulos de análise utilizados, com médias entre 4,26 e 4,63 pontos.

Quanto ao teste estatístico Kruskal-Wallis, os resultados majoritariamente corroboram a existência de níveis assemelhados da importância atribuída às funções de controladoria pelos gestores dos municípios pesquisados. Esta conclusão é pertinente porque foram apurados indicativos de haver divergência quanto ao grau da importância dada às funções de controladoria pelos gestores participantes do estudo apenas em algumas das 29 questões apresentadas nas três perspectivas utilizadas. $\mathrm{Ou}$ seja, somente em dois casos quanto ao número de habitantes do município (Proteção e Controle de Ativos e Contratação e Controle de Seguros) e um caso de cada nas perspectivas quanto ao cargo ocupado pelo gestor (Fiscalização e Cumprimento de Obrigações Legais/Fiscais) e ao tipo de graduação do gestor municipal (Acompanhamento e Realização de Auditoria).

A partir do exposto, pode-se considerar que, na maioria das funções e respectivas atividades que as integram, não há uma distinção estatisticamente 
Importância atribuída pelos Gestores às funções de Controladoria nas Prefeituras Municipais da Associação dos Municípios da Zona de Produção do Rio Grande do Sul Natália da Silva Schio, Rodney Wernke, Antônio Zanin

relevante entre os três grupos de municípios acerca da importância atribuída às funções da controladoria pelos gestores em tela.

Além disso, é importante salientar que, como o foco desta pesquisa foi o ponto de vista dos gestores municipais, esta abordagem se distingue daquela priorizada no estudo de Bonetti et al. (2017), que visou conhecer a opinião dos controllers a respeito das funções de controladoria. Desse modo, obtiveram-se indícios acerca de como os gestores dos municípios abrangidos avaliam as funções desempenhadas pela controladoria, o que pode distinguir-se da opinião dos controllers sobre seu próprio trabalho.

Então, mesmo com a restrição imposta pelo número de prefeituras investigadas, é possível considerar que os resultados citados podem auxiliar na compreensão da importância que a controladoria municipal tem para os usuários das informações provenientes das funções executadas pelos controllers no âmbito dos municípios de pequeno porte considerados neste estudo.

\section{CONCLUSÕES}

Esta pesquisa teve o objetivo de identificar os níveis da importância atribuída às funções de controladoria pelos gestores das prefeituras pertencentes à AMZOP. Assim, considerando o exposto nas seções anteriores, considera-se que o referido objetivo foi atingido, pois foram identificados os achados resumidos a seguir.

Quanto às médias dos níveis da importância atribuída, as quatro funções que receberam mais atenção por parte dos gestores municipais foram: Controle Interno (13,1\%), Contábil (12,84\%), Tributária $(12,75 \%)$ e Controle de Riscos $(12,62 \%)$. Por outro lado, aquelas que menos importância receberam foram: Proteção e Controle de Ativos (12,04\%), Gestão da Informação (12,09\%), Custos (12,15\%) e Gerencialestratégica $(12,4 \%)$. 
Importância atribuída pelos Gestores às funções de Controladoria nas Prefeituras Municipais da Associação dos Municípios da Zona de Produção do Rio Grande do Sul Natália da Silva Schio, Rodney Wernke, Antônio Zanin

No que concerne às médias dos níveis de importância de cada função, representadas pelas questões apresentadas nas tabelas citadas nas seções anteriores, cabe destacar que as três que mais se destacaram em termos das respostas dadas pelos trinta gestores participantes foram Controle Interno (com média de 4,71 pontos), Contábil (com média de 4,62 pontos) e Tributária (com média de 4,58 pontos). Todavia, pelo ângulo daquelas que menos relevância tiveram na visão dos respondentes, cabe citar as seguintes: Proteção e Controle dos Ativos (com média de 4,33 pontos), Gestão da Informação (com média de 4,35 pontos) e Função de Custos (com média de 4,37 pontos).

No que tange ao exame realizado, levando-se em conta os grupos segregados quanto ao número de habitantes, cargo ocupado pelo gestor e a área de graduação do gestor, é interessante ressaltar as seguintes conclusões oriundas do teste estatístico aplicado:

a) Número de habitantes: somente em duas questões (ambas da função Proteção e Controle de Ativos) foi possível rejeitar a hipótese nula, ou seja, constatou-se que havia médias diferentes nos três grupos considerados (até 5.000 habitantes, entre 5.000 e 10.000 habitantes e acima deste patamar) em termos da importância atribuída pelos gestores;

b) Cargo ocupado pelo gestor: quanto ao cargo como variável de agrupamento, em apenas uma das questões (relacionada com a função tributária) houve rejeição da hipótese nula, sendo que esta questionava sobre o envolvimento da controladoria no cumprimento de obrigações legais e fiscais;

c) Área de graduação do gestor: no que se refere aos agrupamentos quanto à graduação dos gestores, houve rejeição da hipótese nula (de igualdade entre as médias) em somente uma questão da função Controle de Riscos.

A partir do exposto, pode-se considerar que, na maioria das funções e respectivas atividades que as integram, não há uma distinção estatisticamente relevante entre os três grupos de municípios acerca da importância atribuída às funções 
Importância atribuída pelos Gestores às funções de Controladoria nas Prefeituras Municipais da Associação dos Municípios da Zona de Produção do Rio Grande do Sul Natália da Silva Schio, Rodney Wernke, Antônio Zanin

da controladoria pelos gestores municipais. Ou seja, somente em algumas das 29 questões apresentadas para cada perspectiva (número de habitantes, cargo e graduação do gestor) foi constatado nível de importância distinto entre os grupos de municípios, sendo duas no caso do tamanho da população e uma de cada quanto ao cargo e à graduação do gestor municipal.

Apesar de o contingente amostral ser reduzido (trinta municípios), acredita-se que esta pesquisa contribui para o universo acadêmico por trazer a visão dos gestores municipais acerca das funções da controladoria. Nesse rumo, no âmbito teórico, considera-se que os achados ora relatados contribuem para aprimorar o conhecimento relativo às funções de controladoria priorizadas no ambiente da administração pública de municípios brasileiros. Com isso, auxiliam no preenchimento parcial de uma lacuna de pesquisa relacionada à importância atribuída pelos gestores às funções de controladoria em prefeituras municipais, conforme discutido em seção precedente.

No que tange às limitações desta pesquisa, cabe salientar o fato de ter abrangido apenas trinta municípios de determinada região gaúcha, o que não permite extrapolar os resultados para outros contextos. Além disso, é pertinente mencionar a própria limitação do tipo de instrumento utilizado, pois os questionários podem conter aspectos que prejudicam a interpretação dos respondentes ou que podem influenciar no tipo de resposta.

Quanto às sugestões para trabalhos futuros, recomenda-se a ampliação da amostra para outros municípios, regiões e estados para confirmar/refutar os achados deste estudo, bem como tentar conhecer os motivos da predileção dos gestores por determinadas funções da controladoria.

\section{REFERÊNCIAS}

Aaker, D. A., Kumar, V., \& Day, G. S. (2001). Marketing research. John Wiley Operations Research \& Sons, New York, 51(4), 509-518. 
Importância atribuída pelos Gestores às funções de Controladoria nas Prefeituras Municipais da Associação dos Municípios da Zona de Produção do Rio Grande do Sul Natália da Silva Schio, Rodney Wernke, Antônio Zanin

Assis, L., Silva, C. L., \& Catapan, A. (2016). As funções da controladoria e sua aplicabilidade na administração pública: uma análise da gestão dos órgãos de controle. Revista Capital Científico - Eletrônica, 14(3), 26-43.

Associação dos Municípios da Zona de Produção do Rio Grande do Sul (AMZOP). 2018. Institucional. Recuperado de: <http://www.amzop.com.br>. Acesso em: 22/jun./2018.

Araújo, D. J. C., Libonati, J. J., Miranda, L. C., \& Ramos, F. S. (2016). Unidades de controle interno dos municípios brasileiros: análise sob a ótica do COSO II. Revista Universo Contábil, 12(2), 39-58.

Barnier, B. (2015). Why controls have become wasteful, a false sense of security, and dangerously distracting - and how to fix it. EDPACS, 51(5), 1-15.

Beuren, I. M., \& Zonatto, V. C. S. (2014). Perfil dos artigos sobre controle interno no setor público em periódicos nacionais e internacionais. Revista de Administração Pública, 48(5), 1135-1164.

Bonetti, A. P. M, Wernke, R., \& Zanin, A. (2017). Funções exercidas pela controladoria das prefeituras municipais do sudoeste do Paraná. Simpósio de Controladoria da UFRPE - Simpcont. Recife, Brasil, 2.

Borinelli, M. L. (2006). Estrutura conceitual básica de controladoria: sistematização à luz da teoria e da práxis. (Tese de Doutorado em Ciências Contábeis). Universidade de São Paulo - USP, São Paulo.

Brasil (1988). Constituição Federal de 1988. Promulgada em 5 de outubro de 1988. Recuperado <http://www.planalto.gov.br/ccivil_03/Constituicao/Constituicao.htm>. Acesso em: 27/ago./2018.

Bruni, A. L. (2012) SPSS: guia prático para pesquisadores. São Paulo: Atlas.

Callado, A. A. C., \& Amorim, T. N. G. F. (2017). Competências da função de controller em hotéis de grande porte da região metropolitana do Recife. Revista Evidenciação Contábil \& Finanças, 5(2), 57-73.

Castellan, C. M. (2010). Quantitative and qualitative research: a view for clarity. International Journal of Education, 2(2), 1. 
Importância atribuída pelos Gestores às funções de Controladoria nas Prefeituras Municipais da Associação dos Municípios da Zona de Produção do Rio Grande do Sul Natália da Silva Schio, Rodney Wernke, Antônio Zanin

Catelli, A. (2012). Visão da controladoria aplicada ao setor público: criando valor para a sociedade. In: Machado, N. et al. GBRSP - Gestão baseada em resultado no setor público: uma abordagem para implementação em prefeituras, câmaras municipais, autarquias, fundações e unidades organizacionais. São Paulo: Atlas.

Cavalcante, D. S., De Luca, M. M. M., Ponte, V. M. R., \& Gallon, A. V. (2012). Características da controladoria nas maiores companhias listadas na BM\&FBOVESPA. Revista Universo Contábil, 8(3),113-134.

Conselho Federal de Contabilidade (CFC). (2008). Resolução 1.135. Aprova a NBC T 16.8 - Controle Interno. Brasília: Diário Oficial da União, 04 de out. 2008.

Committee of Sponsoring Organizations of the Treadway Commission (COSO). (2018). Disponível em: <http:// www.coso.org>. Acesso em: 02/jul./2018.

Cruz, M. C. M. T., Silva, T. A. B., \& Spinelli, M. V. (2016). O papel das controladorias locais no cumprimento da lei de Acesso à Informação pelos municípios brasileiros. Cadernos EBAPE.BR, 14(3), 721-743.

Durigon, A. R., \& Diehl, C. A. (2013). Controladoria no setor público: uma análise dos artigos publicados no congresso USP de controladoria e contabilidade - período de 2001 a 2011. Revista Contabilidade Vista \& Revista. 24(2), 91-109.

Fachini, G. J, Beuren, I. M, \& Nascimento, S. do. (2009). Evidências de isomorfismo nas funções da controladoria das empresas familiares têxteis de Santa Catarina. Congresso Brasileiro de Custos. Fortaleza, Ceará, Brasil, 19.

Fernandes, A. M., \& Galvão, P. R. (2016). A Controladoria como ferramenta de gestão nas micro e pequenas empresas: um estudo da viabilidade e da relação custobenefício. Revista de Tecnologia Aplicada, 5(1), 3-16.

Galvão, P. R. (2016). A implantação do sistema de controle interno em órgãos públicos como tecnologia de redução do conflito de agência pública/governamental. Revista de Tecnologia Aplicada, 5(2), 39-53.

Henrique, J. C., Chagas, L., Guimarães, V. A., \& Leal Júnior, I. C. (2016). Análise da sistemática de controle interno do município de Três Rios. Revista Pensamento Contemporâneo em Administração, 10(3), 31-41.

Instituto Brasileiro de Geografia e Estatística [IBGE]. (2018). Cidades, 2018. Rio de Janeiro: IBGE. Recuperado de: <https://cidades.ibge.gov.br/brasil/rs/panorama>. Acesso em: 27/abr./2019. 
Importância atribuída pelos Gestores às funções de Controladoria nas Prefeituras Municipais da Associação dos Municípios da Zona de Produção do Rio Grande do Sul Natália da Silva Schio, Rodney Wernke, Antônio Zanin

Levine, D. M, Berenson, M. L, \& Stephan, D. (2000). Estatística: teoria e aplicações. Rio de Janeiro: LTC.

Likert, R. (1932). A technique for the measurement of attitudes. Archives of Psychology, 22(140), 44-53.

Lunkes, R. J., Schnorrenberger, D., Gasparetto, V., \& Vicente, E. F. R. (2009). Considerações sobre as funções da controladoria nos Estados Unidos, Alemanha e Brasil. Revista Universo Contábil, 5(4), 63-75.

Lunkes, R.J, Schnorrenberger, D., Rosa, F. S. da. (2013). Funções da controladoria: uma análise no cenário brasileiro. Revista Brasileira de Gestão de Negócios, 15(47), 283-299.

Macedo, F. R., \& Lavarda, C. E. F. (2013). Características da produção científica nacional e internacional sobre orçamento público, orçamento participativo e controladoria pública na primeira década do século XXI. Administração Pública e Gestão Social, 5(1), 70-90.

Malhotra, N. (2012). Pesquisa de marketing. (6a ed.). Porto Alegre: Bookman.

Organização para a Cooperação e Desenvolvimento Econômico (OCDE). (2011). Avaliação da OCDE sobre o sistema de integridade da administração pública federal brasileira: gerenciando riscos por uma administração pública mais íntegra. [S.I.]: Avaliações da OCDE sobre Governança Pública, 2011. (Sumário executivo). Recuperado de: <http:// www.cgu.gov.br/publicacoes/AvaliacaolntegridadeBrasileiraOCDE/Avaliacaolntegrid adeBrasileiraOCDE.PDF>. Acesso em: 04/ago./2018.

Oliveira Júnior, N. J., Chaves Júnior, O. D. L., \& Lima, M. S. (2009). A controladoria nas organizações públicas municipais: um estudo de caso. Revista Universo Contábil, $5(1), 38-54$.

Pinheiro, F. M. G., Lopes, L. M. S., Rocha, J. S., \& Dias Filho, J. M. (2013). Desafios da controladoria pública no contexto da Copa do Mundo de 2014. Contabilidade, Gestão e Governança, 16(3), 108-123.

Pinsonneault, A., \& Kraemer, K. L. (1993). The impact of information technology on middle managers. MIS Quarterly, 17(3), 271-292.

Rauen, F. J. (2015). Roteiros de iniciação científica: os primeiros passos da pesquisa científica desde a concepção até a produção e a apresentação. Palhoça: Ed. Unisul. 
Importância atribuída pelos Gestores às funções de Controladoria nas Prefeituras Municipais da Associação dos Municípios da Zona de Produção do Rio Grande do Sul Natália da Silva Schio, Rodney Wernke, Antônio Zanin

Richardson, R. J. (1999). Pesquisa social: métodos e técnicas. (3a ed.). São Paulo: Atlas.

Silva, E. F. (2013). Controladoria na administração pública. São Paulo: Atlas.

Silva, N. D. R., Carneiro, A. F., \& Ramos, E. G. (2015). Controladoria no setor público: uma comparação entre as leis de criação em quatro dos maiores municípios de Rondônia e a literatura. Revista Evidenciação Contábil \& Finanças, 3(2), 73-87.

Slomski, V. (2009). Controladoria e governança corporativa na gestão pública. São Paulo: Atlas.

Souza, F. J. V., Barros, C. C., Araújo, A. O., \& Silva, M. C. (2013). Perfil dos artigos sobre controladoria publicados em periódicos nacionais de contabilidade. Revista Catarinense da Ciência Contábil, 12(37), 35-50.

Souza Junior, M., Silva, M. Z. (2016). Gestão pública estadual: percepção dos gestores sobre a qualidade dos controles internos. Revista Catarinense da Ciência Contábil, 15(46), 47-60.

Souza, R. G., Souto, S. D. A. S., Nicolau, A. M. (2017). Em um mundo de incertezas: um Survey sobre controle interno em uma perspectiva pública e privada. Revista Contemporânea de Contabilidade, 14(31), 155-176.

Suzart, J. A. S., Marcelino, C. V., \& Rocha, J. S. (2011). As instituições brasileiras de controladoria pública - teoria versus prática. Contabilidade, Gestão e Governança, 14(1), 44-56.

Vogt, M., Degenhart, L., \& Lavarda, C. E. F. (2017). Motivações, habilidades e competências do controller na percepção de alunos que cursam pós-graduação em controladoria. Revista Catarinense da Ciência Contábil, 16(48), 105-123.

Wilson, J. D., Roehl-Anderson, J. M., \& Bragg, S. M. (1995). Controllership: the work of the managerial accountant. (5th ed.). New York: John Wiley \& Sons, Inc.

Wright, G. A., Callado, A. L. C., \& Melo, M. M. D. (2013). As funções da controladoria no setor público: a percepção de quem faz a Controladoria Geral da União. Congresso USP de Controladoria e Contabilidade. São Paulo, Brasil, 13.

Data de Submissão: 17/11/2018

Data de Aceite: 10/07/2019 